\title{
PENGARUH PERENCANAAN PAJAK DAN KONSERVATISME AKUNTANSI TERHADAP NILAI PERUSAHAAN
}

\author{
Habibah $^{1}$, Lyandra Aisyah Margie ${ }^{2}$ \\ ${ }^{1-2}$ Program Studi Akuntansi Fakultas Ekonomi Universitas Pamulang \\ E-mail: habibahrh@yahoo.co.id
}

\begin{abstract}
ABSTRAK
Penelitian ini bertujuan untuk melihat pengaruh perencanaan pajak dan konservatisme akuntansi terhadap nilai perusahaan pada perusahaan sub sektor makanan dan minuman yang tercatat di Bursa Efek Indonesia untuk periode tahun 2014-2018.

Metode yang digunakan didalam penelitian ini adalah pendekatan kuantitatif dengan analisis regresi linier berganda. Jumlah sampel yang digunakan didalam penelitian adalah 9 perusahaan.

Hasil pengolahan data yang dilakukan menemukan bahwa secara simultan, perencanaan pajak dan konservatisme akuntansi berpengaruh signifikan terhadap nilai perusahaan namun secara parsial, hanya perencanaan pajak yang berpengaruh signifikan terhadap nilai perusahaan.
\end{abstract}

Keywords : Perencanaan Pajak; Konservatisme Akuntansi; Nilai Perusahaan

\section{ABSTRACT}

This study aims to look at the influence of tax planning and accounting conservatism on company value in food and beverage sub-sector companies which is listed on the Indonesian Stock Exchange for the period 2014-2018.

The method used in this study is a quantitative approach with multiple linear regression analysis. The number of samples used in the study was 9 compa pnies.

The results of data processing found that simultaneously, tax planning and accounting conservatism have a significant effect on the value of the company but in part, only tax planning has a significant effect on the value of the company.

Keywords : Tax Planning; Accounting Conservatism; Company Value

\section{PENDAHULUAN}

Indonesia telah bersiap di dalam memasuki masa Revolusi Industri 4.0. Untuk menghadapi revolusi tersebut, pemerintah telah menyiapkan inisiatif "Making Indonesia 4.0". Industri food and beverage di Indonesia merupakan salah satu sektor unggulan didalam inisiatif ini. Industri ini juga adalah industri yang memiliki kontribusi terbesar didalam industri pengolahan yang ada di Indonesia.

Industri di Indonesia salah satunya ditopang oleh indutri food and beverage. Peran penting ini sebagaimana dikatakan oleh Kementerian Perindustrian, dapat dilihat dari kontribusi industri ini terhadap produk domestik bruto (PDB), industri non migas dan kenaikan realisasi investasi yang terus konsisten dan signifikan.

Nilai perusahaan yang dimaksimalkan juga akan membuat tujuan utama perusahaan menjadi maksimal, sehingga maksimalisasi nilai perusahaan bagi suatu perusahaan menjadi arti yang penting. Keinginan pemilik perusahaan terkait prestasi yang sesuai pastinya adalah nilai perusahaan yang meningkat, imbas dari nilai perusahaan yang meningkat, maka para pemilik juga akan meningkat kemakmurannya.

Perencanaan Pajak merupakan salah satu faktor yang turut mempengaruhi Nilai Perusahaan. Perencanaan pajak adalah usaha yang dilakukan oleh perusahaan supaya beban 
pajak yang ditanggung oleh perusahaan rendah. Perencanaan pajak dilakukan dengan cara mengelola dan merekayasa transaksi yang terjadi dalam perusahaan yang bertujuan untuk memaksimalkan laba.

"Perencanaan pajak yang baik akan meminimalisir beban pajak yang harus dibayar oleh perusahaan. Dalam melakukan perhitungan dan pembayaran pajak, perusahaan biasanya melakukan upaya-upaya agar beban yang ditimbulkan dari pajak dapat ditekan seminimal mungkin untuk memperoleh peningkatan laba bersih setelah pajak, dimana peningkatan laba bersih setelah pajak akan berdampak pada kepercayaan investor terhadap perusahaan yang pada akhirnya akan meningkatkan nilai perusahaan" (Lestari et al, 2014 dalam (Hidayat \& Hairi, 2016).

Dalam penelitian yang dilakukan oleh Muhammad Hidayat et al., (2016) mengatakan bahwa Perencaaan Pajak berpengaruh negatif signifikan terhadap Nilai Perusahaan, sedangkan menurut Hetti Herawati et all (2016) mengatakan bahwa Perencanaan Pajak memiliki pengaruh yang signifikan terhadap Nilai Perusahaan.

Konservatisme Akuntansi juga mempengaruhi Nilai Perusahaan. "Konservatisme dapat didefinisikan sebagai tendensi yang dimiliki oleh seorang akuntan yang mensyaratkan tingkat verifikasi yang lebih tinggi untuk mengakui laba dibandingkan dengan mengakui rugi. Prinsip konservatisme juga seringkali dikaitkan dengan kualitas laba dan menjadi nilai perusahaan. Konservatisme Akuntansi akan mempengaruhi baik kualitas laba yang dilaporkan dalam laporan keuangan maupun kualitas akun finansial (seperti aset dan hutang) yang dilaporkan dalam neraca perusahaan" (Manik, 2018). Seperti yang di teliti oleh Tumpal Manik (2018) mengatakan bahwa Konservatisme Akuntansi berpengaruh signifikan terhadap Nilai Perusahaan, Shelly Elgy Augustine (2016) mengatakan bahwa Konservatisme Akuntansi berpengaruh negatif terhadap Nilai Perusahaan, sedangkan Ulfa Rafida Isnaningrum (2016) mengatakan bahwa Konservatisme Akuntansi tidak berpengaruh secara signifkan terhadap Nilai Perusahaan.

Penelitian yang dilakukan oleh (Isnaningrum, 2016) menemukan bahwa Konservatisme Akuntansi tidak berpengaruh terhadap Nilai Perusahaan, karena masih rendahnya konservatisme yang diterapkan pada perusahaan perbankan. Nilai perusahaan akan menurun sebab kencederungan laporan keuangan yang menjadi bias serta tidak mencerminkan keadaan perusahaan yang real akibat metode konservatisme ini. Karena penerapan Konservatisme pada perusahaan perbankan masih rendah, penelitian yang akan dilakukan adalah pada perusahaan manufaktur yang akan diteliti selanjutnya.

Berdasarkan uraian diatas dan adanya penemuan dan research gap dengan penelitian sebelumnya, untuk itu penulis tertarik meneliti dengan judul "Pengaruh Perencanaan Pajak dan Konservatisme Akuntansi Terhadap Nilai Perusahaan (Studi Empiris pada Perusahaan Manufaktur subsektor makanan dan minuman yang Terdaftar di Bursa Efek Indonesia Tahun 2014-2018)".

\section{KAJIAN PUSTAKA}

\section{Signalling Theory}

Pentingnya suatu informasi yang perusahaan miliki dapat dipahami melalui teori sinyal ini. (Spence, 2002 dalam Lesmana \& Sukartha, 2017) menyatakan bahwa "Tujuan dari teori sinyal adalah untuk meminimalisir terjadinya ketidakseimbangan informasi yang dimiliki pihak manajer dan pihak lain (pemegang saham dan pihak eksternal)". "Manajer yang lebih dekat dengan perusahaan memiliki informasi yang dapat menggambarkan prospek perusahaan di masa depan, sedangkan pemegang saham maupun pihak eksternal tidak memilikinya" (Yuliawan, 2015). Kepercayaan investor dapat ditarik dengan penyampaian informasi lebih lanjut oleh perusahaan mengenai aktivitas yang mereka lakukan (Birjandi et al., 2015) dalam (Lesmana \& Sukartha, 2017). 


\section{Nilai Perusahaan}

"Nilai perusahaan dapat diukur melalui nilai harga saham dipasar berdasarkan terbentuknya harga saham perusahaan dipasar, yang merupakan refleksi penilaian oleh publik terhadap kinerja perusahaan secara riil. Dikatakan secara riil karena terbentuknya harga di pasar merupakan bertemunya titik-titik kestabilan kekuatan permintaan dan titik-titik kestabilan kekuatan penawaran harga yang secara riil terjadi transaksi jual beli surat berharga di pasar modal antara para penjual (emiten) dan para investor, atau sering disebut ekuilibrium pasar. Oleh karena itu, dalam teori keuangan pasar modal harga saham dipasar disebut sebagai konsep nilai perusahaan" (Harmono, 2015:50).

"Semakin tinggi harga saham maka semakin tinggi pula nilai suatu perusahaan. Nilai perusahaan dapat tercermin melalui harga saham, bagi perusahaan yang menerbitkan saham dipasar modal. Semakin tinggi harga saham berarti semakin tinggi tingkat pengembalian kepada investor dan itu berarti semakin tinggi nilai perusahaan yang terkait dengan tujuan dariperusahaan itu sendiri, yaitu memaksimalkan kemakmuran pemegang saham" (Widnyantari dan Yadnya, 2017).

\section{Perencanaan Pajak}

Sunday, 2016 "Perencanaan pajak adalah langkah awal dalam manajemen pajak. Pada tahap ini dilakukan pengumpulan dan penelitian terhadap peraturan perpajakan agar dapat diseleksi jenis tindakan penghematan pajak yang akan dilakukan”. Pada umumnya, kewajiban pajak dikecilkan dengan perencanaan pajak yang ditekan. Hal ini dapat dilihat dari dua definisi perencanaan pajak (tax planning) dibawah ini.

1. "Tax Planning is the systematic analysis of deferring tax options aimed at the minuimazation of tax liability in current and future tax periods" (Crumbley D. Larry, Friedman Jack P., Anders Susan B., 1994).

2. "Tax planning is arrangements of a person's business and/or private affairs in order to minimize tax liability" (Lyons Susan M., 1996).

Menurut (Pohan, 2013: 18 dalam (Herawati \& Ekawati, 2016), "Perencanaan pajak (tax planning) adalah proses mengorganisasi usaha wajib pajak baik pribadi maupun badan usaha sedemikian rupa dengan memanfaatkan berbagai celah kemungkinan yang dapat ditempuh oleh perusahaan dalam koridor ketentuan peraturan perpajakan (loophole), agar perusahaan dapat membayar pajak dalam jumlah minimum".

\section{Konservatisme Akuntansi}

"Konservatisme dalam FASB Statement of Concept No.2 adalah reaksi yang hati-hati terhadap ketidakpastian dengan mencoba menyakinkan bahwa ketidakpastian risiko yang ada pada kondisi bisnis cukup layak untuk dipertimbangkan. Konservatisme merupakan praktik akuntansi dengan mengurangi laba (dan menurunkan nilai aktiva bersih) ketika menghadapi praktik bad news, akan tetapi tidak meningkatkan laba (dan menaikkan nilai aktiva bersih) ketika menanggapi good news" (Basu, 1997 dalam (Ulfa, 2016).

"Konservatisme merupakan konvensi atau prosedur dalam penyusunan laporan keuangan yang sangat penting dalam akuntansi, sehingga disebut sebagai prinsip akuntansi yang dominan. Konvensi dalam konservatisme menjadi pertimbangan dalam akuntansi dikarenakan aktivitas perusahaan dilingkupi oleh ketidakpastian. Konsep konservatisme menyatakan bahwa dalam keadaan yang tidak pasti manajer perusahaan akan menentukan pilihan perlakuan atau tindakan akuntansi yang akan dipilih berdasarkan pada keadaan, harapan kejadian atau hasil yang dianggap menguntungkan bagi perusahaan" (Ulfa, 2016).

"Konservatisme akuntansi memiliki perannya sebagai fungsi monitoring terhadap kebijakan investasi perusahaan. Dengan mensyaratkan pengakuan yang lebih cepat atas ekspektasi kerugian, konservatisme membantu manajer untuk mengidentifikasikan proyek yang memiliki investasi dengan kinerja buruk. Konservatisme juga akan membatasi kerugian yang mungkin muncul dari keputusan investasi yang berkinerja buruk" (Augustine, 2016). 


\section{Penelitian-Penelitian Terdahulu}

Untuk mendapat bahan pembandingan dan acuan serta menghindari anggapan kesamaan maka dibuatlah ringkasan penelitian-penelitian terdahulu. Untuk itu peneliti mencantumkan hasil-hasil penelitian terdahulu sebagai berikut:

1. Peneliti Muhammad Hidayat et all (2016) mengatakan bahwa Perencaaan Pajak berpengaruh negatif signifikan terhadap Nilai Perusahaan.

2. Peneliti Hetti Herawati et all (2016) mengatakan bahwa Perencanaan Pajak memiliki pengaruh yang signifikan terhadap Nilai Perusahaan.

3. Penelitian Tumpal Manik (2018) mengatakan bahwa Konservatisme Akuntansi berpengaruh signifikan terhadap Nilai Perusahaan.

4. Peneliti Shelly Elgy Augustine (2016) mengatakan bahwa Konservatisme Akuntansi berpengaruh negatif terhadap Nilai Perusahaan

5. Peneliti Ulfa Rafida Isnaningrum (2016) mengatakan bahwa Konservatisme Akuntansi tidak berpengaruh secara signifkan terhadap Nilai Perusahaan.

6. Penelitian yang dilakukan oleh (Isnaningrum, 2016) Konservatisme Akuntansi tidak berpengaruh terhadap Nilai Perusahaan.

7. Peneliti Pandu Dewanata (2016) mengatakan bahwa terdapat hubungan positif antara Perencanaan Pajak terhadap Nilai Perusahaan.

\section{Kerangka Berpikir}

Kerangka berpikir dalam penelitian ini dapat dijelaskan seperti gambar berikut:

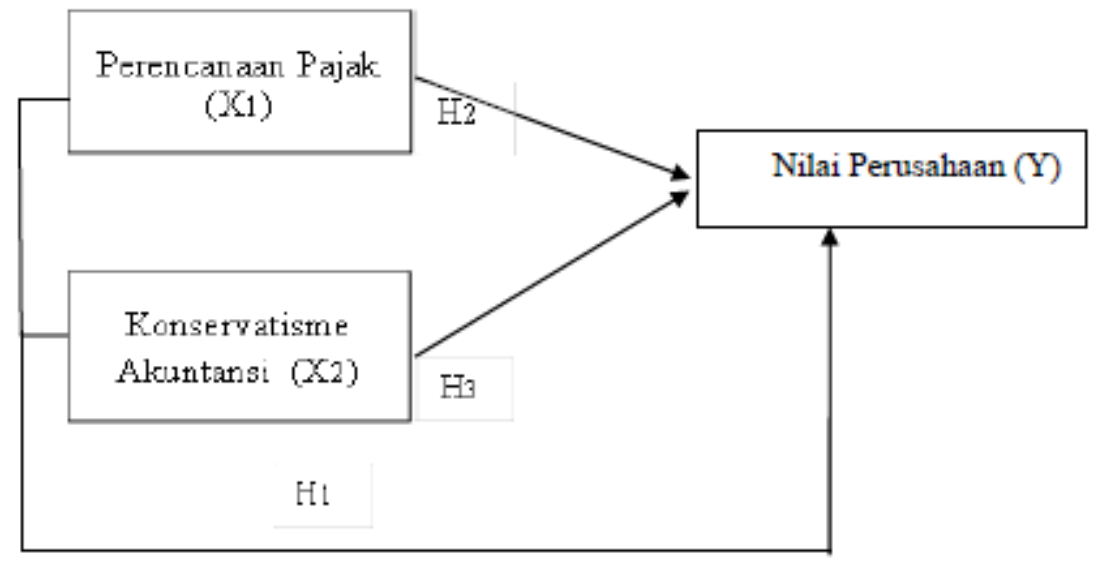

Gambar 2.1: Kerangka Berpikir

\section{Perumusan Hipotesis Penelitian}

1. Pengaruh Perencanaan Pajak dan Konservatisme Akuntansi secara simultan terhadap Nilai Perusahaan

Nilai Perusahaan adalah pencerminan kinerja perusahaan yang terbentuk dari permintaan dan penawaran harga saham di pasar modal yang menggambarkan kinerja perusahaan dari hasil penilaian masyarakat. Peningkatan nilai perusahaan bisa dicapai oleh perusahaan yang melakukan perencanaan pajak. Perusahaan yang melakukan perencanaan pajak dapat membayarkan utang pajaknya secara lebih efektif dan kewajiban perpajakannya Nampak lebih tertib. Dalam penelitian yang dilakukan oleh Muhammad Hidayatt al., (2016) mengatakan bahwa Perencaaan Pajak berpengaruh negative signifikan terhadap Nilai Perusahaan, sementara Pandu Dewanata (2016) mengatakan bahwa terdapat hubungan positif antara Perencanaan Pajak terhadap Nilai Perusahaan.

Nilai Perusahaan juga dipengaruhi oleh Konservatisme Akuntansi. Fungsi monitoring dimiliki konservatisme akuntansi terhadap kebijakan investasi perusahaan, dengan syarat, pengakuan yang lebih cepa tatas kerugian yang diharapkan sehingga konservatisme sendiri membantu manajer dalam mengidentifikasi proyek investasi yang sekiranya memiliki kinerja yang tidak baik. Dalam penelitian yang dilakukan Tumpal Manik (2018) mengatakan 
bahwa Konservatisme Akuntansi berpengaruh signifikan terhadap Nilai Perusahaan sedangkan Shelly Elgy Augustine (2016) mengatakan bahwa Konservatisme Akuntansi berpengaruh negatif terhadap Nilai Perusahaan.

$\mathrm{H}_{1}$ : Perencanaan Pajak dan Konservatisme Akuntansi berpengaruh secara simultan terhadap Nilai Perusahaan

2. Pengaruh Perencanaan Pajak terhadap Nilai Perusahaan

Upaya perusahaan agar beban pembayaran pajak perusahaan rendah disebut perencanaan pajak. Perencanaan ini dilakukan dengan cara pengelolaan dan perekayasaan transaksi yang perusahaan lakukan dengan tujuan menaikkan laba.

Dengan melaksanakan perencaan pajak, pajak terutang perusahaan bisa lebih efektif dibayarkan serta menampakkan tertib kewajiban perpajakan sehingga nilai perusahaan akan naik. Dalam penelitian yang dilakukan oleh Muhammad Hidayat et al, (2016) mengatakan bahwa Perencaaan Pajak berpengaruh signifikan terhadap Nilai Perusahaan, Pandu Dewanata (2016) mengatakan bahwa terdapat hubungan positif antara Perencanaan Pajak terhadap Nilai Perusahaan, sedangkan menurut Hetti Herawati et all (2016) mengatakan bahwa Perencanaan Pajak memiliki pengaruh yang signifikan terhadap Nilai Perusahaan. Fadli et al., (2016) dan Indradi (2018) yang menemukan hasil yang sama.

\section{H2: Perencanaan Pajak berpengaruh signifikan terhadap Nilai Perusahaan}

3. Pengaruh Konservatisme Akuntansi terhadap Nilai Perusahaan

Konservatisme dapat dilihat dari kecenderungan yang seorang akuntan miliki, yang memberi syarat tingkat verifikasi yang lebih tinggi juga untuk mengakui keuntungan dibandingkan untuk mengakui kerugian, prinsip konservastisme ini juga seringkali disandingkan dengan kualitas dari laba yang menjadi nilai perusahaan, konservatisme akuntansi akan membuat kualitas laba berpengaruh Ketika dilaporkan ke dalam laporan keuangan, juga mempengaruhi kualitas akun lain seperti aktiva dan pasiva yang dilaporakan dalam neraca perusahaan.

Konservatisme akuntansi juga berperan sebagai pengawas kebijakan atas investasi perusahaan. Dengan melakukan pengakuan atas kemungkinan kerugian yang lebih cepat, konservatisme sendiri membantu manajer untuk mengindetifikasi proyek investasi yang dianggap memiliki kinerja tidak baik. Konservatisme akiuntansi juga akan membatasi kemungkinan kerugian yang timbul dari keputusan investasi yang memiliki kinerja tidak baik.

Dalam penelitian yang dilakukan Tumpal Manik (2018) mengatakan bahwa Konservatisme Akuntansi berpengaruh signifikan terhadap Nilai Perusahaan, Shelly Elgy Augustine (2016) mengatakan bahwa Konservatisme Akuntansi berpengaruh negatif terhadap Nilai Perusahaan, sedangkan Ulfa Rafida Isnaningrum (2016) mengatakan bahwa Konservatisme Akuntansi tidak berpengaruh secara signifkan terhadap Nilai Perusahaan.

\section{H3: Konservatisme Akuntansi berpengaruh signifikan terhadap Nilai Perusahaan}

\section{METODE PENELITIAN}

\section{Ruang Lingkup Penelitian}

Penelitian ini bersifat kuantitatif dan merupakan studi empiris yang dilakukan untuk membuktikan adanya pengaruh perencanaan pajak dan konservatisme akuntansi terhadap nilai perusahaan. Penelitian ini dilakukan dengan mengambil data sekunder dan mengunduh melalui website www.idx.co.id. annual report dari perusahaan food and beverage yang terdaftar di BEI.

\section{Populasi}

Populasi dalam penelitian ini adalah perusahaan food and beverage yang terdaftar di Bursa Efek Indonesia (BEI) dari tahun 2014 sampai tahun 2018. Penelitian ini menggunakan laporan keuangan tahun 2014 sampai tahun 2018 sebagai sampel. Tahun 2014 sampai 2018 dipilih karena dianggap dapat menggambarkan pasar modal Indonesia yang relative tidak 
lama. Dengan menggunakan sampel ini, hasil penelitian diharapkan lebih relevan dalam memahami kondisi terkini perusahaan food and beverage.

\section{Sampel}

Metode purposive sampling digunakan dalam penentuan sampel perusahaan dengan tujuan untuk mendapatkan sampel yang representatives sesuai dengan kriteria yang ditetapkan.

\section{Metode Penentuan Populasi dan Sampel}

Dalam penelitian ini, untuk mengumpulkan data dalam penelitian ini digunakan metode dokumentasi, yaitu dengan cara mengumpulkan, mencatat dan mengkaji data sekunder.

\section{Operasional Variabel Penelitian}

Adapun definisi operasional variabel masing-masing variabel dan indikatornya adalah sebagai berikut:

Tabel 3.1: Definisi Operasional Variabel

\begin{tabular}{|c|c|c|c|c|}
\hline No & Variabel & Definisi & Indikator & $\begin{array}{c}\text { Skala } \\
\text { Pengukuran }\end{array}$ \\
\hline 1 & $\begin{array}{l}\text { Independen: } \\
\text { Perencanaan } \\
\text { Pajak }\end{array}$ & $\begin{array}{l}\text { Meminimumkan kewajiban } \\
\text { pajak. }\end{array}$ & $\begin{array}{l}\text { ETR = Beban } \\
\text { Pajak } \\
\text { Penghasilan / } \\
\text { Laba Bersih } \\
\text { Sebelum Pajak }\end{array}$ & Rasio \\
\hline 2 & $\begin{array}{l}\text { Independen: } \\
\text { Konservatisme } \\
\text { Akuntansi }\end{array}$ & $\begin{array}{l}\text { "Reaksi yang hati-hati } \\
\text { terhadap ketidakpastian } \\
\text { dengan mencoba } \\
\text { menyakinkan bahwa } \\
\text { ketidakpastian risiko yang } \\
\text { ada pada kondisi bisnis } \\
\text { cukup layak untuk } \\
\text { dipertimbangkan" (FASB } \\
\text { Statement of Concept No.2) }\end{array}$ & $\begin{array}{l}\text { CONACC }= \\
(\mathrm{NIO}+\mathrm{DEP}- \\
\mathrm{CFO}) \times \quad(- \\
\text { 1)/TA }\end{array}$ & Rasio \\
\hline 3 & $\begin{array}{l}\text { Dependen: } \\
\text { Nilai } \\
\text { Perusahaan }\end{array}$ & $\begin{array}{l}\text { Adalah rasio hasil } \\
\text { perbandingan antara harga } \\
\text { pasar perlembar salam dan } \\
\text { labar perlembar saham. }\end{array}$ & $\begin{array}{l}\text { PER = Harga } \\
\text { Pasar } \\
\text { Perlembar } \\
\text { Saham / Laba } \\
\text { Perlembar } \\
\text { Saham }\end{array}$ & Rasio \\
\hline
\end{tabular}

\section{Metode Analisis Data}

Data yang diperoleh akan diolah sesuai dengan kepentingan penelitian dan selanjutnya disajikan dalam bentuk tabel dengan dibantu program Microsoft Excel dan selanjutnya dilakukan analisis statistik dengan bantuan program SPSS 24.

\section{HASIL DAN PEMBAHASAN \\ Deskripsi Objek Penelitian}

Populasi dalam penelitian ini adalah seluruh perusahaan food and beverage yang terdaftar di BEI selama periode tahun 2014 sampai tahun 2018. Sampel perusahaan yang diperoleh dan memenuhi kriteria adalah sebanyak 9 perusahaan, dimana penelitian dilakukan selama lima tahun sehingga terkumpul sebanyak 45 sampel.

Data penelitian ini diperoleh dari laporan keuangan dan annual report yang diunduh dari situs resmi yaitu website www.idx.co.id. Fokus penelitian ini adalah ingin melihat pengaruh perencanaan pajak dan konservatisme akuntansi terhadap nilai perusahaan.

\section{Sampel Penelitian}

Data yang digunakan untuk diteliti berupa laporan tahunan serta annual report selama 5 tahun. Langkah awal dalam penelitian adalah melakukan penentuan sampel berdasarkan kriteria dengan teknik purposive sampling. Jumlah perusahaan yang menjadi populasi dalam penelitian ini adalah sembilan. Proses pemilihan sampel berdasarkan kriteria dapat dilihat pada tabel 4.1 berikut: 
Tabel 4.1: Kriteria Penarikan Sampel

\begin{tabular}{|c|c|c|c|}
\hline No & Kriteria & Jumlah & Sampel \\
\hline 1 & $\begin{array}{l}\text { Perusahaan sub sektor food and beverage yang } \\
\text { terdaftar di BEI }\end{array}$ & & 18 \\
\hline 2 & $\begin{array}{l}\text { Perusahaan food and beverage yang selama } \\
\text { periode pengamatan tidak mempublikasikan } \\
\text { financial report dan annual report. }\end{array}$ & (8) & 10 \\
\hline 3 & $\begin{array}{l}\text { Perusahaan yang penyajian laporan } \\
\text { keuangannya disajikan dengan mata uang asing }\end{array}$ & - & 10 \\
\hline 4 & $\begin{array}{l}\text { Perusahaan yang mengalami kerugian selama } \\
\text { periode tahun pengamatan }\end{array}$ & (1) & 9 \\
\hline 5 & $\begin{array}{l}\text { Jumlah sampel perusahaan yang memenuhi } \\
\text { kriteria }\end{array}$ & & 45 \\
\hline
\end{tabular}

\section{Analisis Statistik Deskriptif}

Pengujian ini membuat hasil penelitian diuji secara generalisasi berdasarkan sebuah sampel. Analisis statistik deskriptif memberikan deskripsi atau gambaran mengenai karakteristik suatu data yang dapat dilihat dari nilai maksimum, nilai minimum, nilai rata-rata (mean) serta standar deviasi. Dibawah ini merupakan hasil dari analisis statistik deskriptif penelitian ini:

Tabel 4.3: Hasil Analisis Statistik Deskriptif

\begin{tabular}{|l|c|c|c|c|c|}
\hline & $\mathrm{N}$ & Minimum & Maximum & Mean & Std. Deviation \\
\hline $\begin{array}{l}\text { Perencanaan } \\
\text { Pajak }\end{array}$ & 45 & 1.91 & 1.97 & 1.9343 & .01157 \\
\hline $\begin{array}{l}\text { Konservati } \\
\text { sme }\end{array}$ & 45 & 2.01 & 2.17 & 2.0595 & .03361 \\
$\begin{array}{l}\text { Akuntansi } \\
\text { Nilai Perusahaan }\end{array}$ & 45 & .95 & 14.26 & 4.9602 & 2.47612 \\
\hline $\begin{array}{l}\text { Valid N } \\
\text { (listwise) }\end{array}$ & 45 & & & & \\
\hline
\end{tabular}

Sumber: Data diolah '20'21

Tabel diatas menggambarkan statistik deskriptif dari seluruh variabel yang digunakan dalam penelitian ini. Nilai maksimum menggambarkan nilai paling besar dari hasil pengolahan dan analisis data yang telah dilakukan. Nilai minimum menggambarkan nilai terkecil yang diperolehnya. Sedangkan mean menunjukkan nilai rata-rata dari masing-masing variabel.

\section{Hasil Uji Asumsi Klasik}

\section{Uji Normalitas}

"Tujuan uji normalitas adalah untuk menguji apakah dalam model regresi, variabel independent, variabel dependen, atau keduanya mempunyai distribusi normal ataukah tidak. Model regresi yang baik adalah distribusi normal atau mendekati normal" (Ghozali, 2011:161). Pada penelitian ini untuk menguji normalitas data digunakan uji one-sample kolmogorov-smirnov sebagai berikut:

\begin{tabular}{|c|c|c|}
\hline & & Unstandardized Residual \\
\hline \multicolumn{2}{|l|}{$\mathrm{N}$} & 45 \\
\hline \multirow{2}{*}{ Normal Parameters ${ }^{\mathrm{a}, \mathrm{b}}$} & Mean & $-6,8472515$ \\
\hline & $\begin{array}{l}\text { Std. } \\
\text { Deviation }\end{array}$ & 19,93302371 \\
\hline \multirow{3}{*}{$\begin{array}{l}\text { Most Extreme } \\
\text { Differences }\end{array}$} & Absolute &, 114 \\
\hline & Positive &, 114 \\
\hline & Negative &,- 071 \\
\hline \multicolumn{2}{|l|}{ Test Statistic } &, 114 \\
\hline \multicolumn{2}{|l|}{ Asymp. Sig. (2-tailed) } & $200^{\mathrm{c}, \mathrm{d}}$ \\
\hline \multicolumn{3}{|c|}{ a. Test distribution is Normal. } \\
\hline \multicolumn{3}{|c|}{ b. Calculated from data. } \\
\hline \multicolumn{3}{|c|}{ c. Lilliefors Significance Correction. } \\
\hline \multicolumn{3}{|c|}{ d. This is a lower bound of the true significance. } \\
\hline
\end{tabular}

Sumber: Data diolah 2021 
Berdasarkan tabel diatas diketahui bahwa nilai signifikansi sebesar 0,200 lebih besar dari (>) 0,05 sehingga dapat kesimpulan yang dapat ditarik adalah data yang diuji berdistribusi normal.

\section{Uji Multikolinieritas}

"Uji multikolinieritas bertujuan untuk menguji apakah model regresi ditemukan adanya korelasi antar variabel independen. Model regresi yang baik seharusnya tidak terjadi korelasi diantara variabel independen" (Ghozali, 2011:105). "Deteksi ada atau tidaknya multikolinieritas dalam model regresi adalah dilihat dari besaran VIF (variance inflation factor) dan Tolerance (TOL). Regresi bebas dari masalah multikolinieritas jika nilai VIF < 10 dan nilai TOL > 0,10" (Ghozali, 2011:106).

Tabel 4.5: Hasil Uji Multikolinieritas

\begin{tabular}{|c|c|c|c|c|c|c|c|c|}
\hline \multicolumn{9}{|c|}{ Coefficients $^{\mathrm{a}}$} \\
\hline \multirow{2}{*}{\multicolumn{2}{|c|}{ Model }} & \multicolumn{2}{|c|}{$\begin{array}{l}\text { Unstandardized } \\
\text { Coefficients }\end{array}$} & \multirow{2}{*}{$\begin{array}{c}\text { Standardized } \\
\text { Coefficients } \\
\text { Beta }\end{array}$} & \multirow[b]{2}{*}{$\mathrm{t}$} & \multirow[b]{2}{*}{ Sig. } & \multicolumn{2}{|c|}{ Collinearity Statistics } \\
\hline & & B & $\begin{array}{l}\text { Std. } \\
\text { Error }\end{array}$ & & & & Tolerance & VIF \\
\hline \multirow[t]{3}{*}{1} & (Constant) & $-38,144$ & 30,706 & & 1,242 &, 221 & & \\
\hline & $\begin{array}{l}\text { Perencanaan } \\
\text { pajak }\end{array}$ & 291,324 & 110,969 &, 373 & 2,625 &, 012 & ,998 & 1,002 \\
\hline & $\begin{array}{l}\text { Konservatisme } \\
\text { akuntansi }\end{array}$ & 26,670 & 35,684 &, 106 &, 747 & ,459 & ,998 & 1,002 \\
\hline
\end{tabular}

Sumber: Data diolah 2021

Berdasarkan tabel diatas diketahui bahwa kedua variabel independen tidak ada yang memiliki nilai VIF (variance inflation factor) > 10 dan memiliki nilai Tolerance $<0,10$ sehingga ditraik kesimpulan bahwa model regresi penelitian ini tidak mengalami multikolonieritas.

\section{Uji Heteroskedastisitas}

Menurut Ghozali (2011), "Uji heteroskedastisitas digunakan untuk melihat keberadaan penyimpangan asumsi klasik heteroskedastisitas atau ketidaksamaan dari residual untuk semua pengamatan pada model regres". Metode pengujian yang digunakan dalam penelitian ini adalah Uji runs test. Berdasarkan hasil pengolahan data, maka hasil uji runs test dapat dilihat sebagai berikut:

Tabel 4.6: Hasil Uji Runs Test

\begin{tabular}{|l|r|}
\hline & ABS RES \\
\hline Test Value $^{\mathrm{a}}$ & 13,91 \\
\hline Cases $<$ Test Value & 22 \\
\hline Cases $>=$ Test Value & 23 \\
\hline Total Cases & 45 \\
\hline Number of Runs & 18 \\
\hline Z & $-1,505$ \\
\hline Asymp. Sig. (2-tailed) &, 132 \\
\hline a. Median & \\
\hline
\end{tabular}

Sumber: Data diolah 2021

Nilai signifikansi variable memberikan gambaran apakah model penelitian mengalami gejala heteroskedastisitas. Apabila nilai Asymp. Sig. (2-tailed) > dari tingkat $\alpha$ 0,05 (5\%) maka Ho diterima yang artinya tidak terjadi gejala heteroskedastisitas.

Berdasarkan hasil perhitungan diatas diketahui bahwa tiap tiap variable memiliki nilai sig. lebih besar (>) dari tingkat $\alpha 0,05$ (5\%), sehingga dapat disimpulkan bahwa model penelitian ini tidak terjadi gejala heteroskedastisitas.

\section{Uji Autokorelasi}

Tujuan uji ini adalah menguji apakah dalam model regresi linier terdapat korelasi antara kesalahan pengganggu pada periode $t$ dengan kesalahan pengganggu pada periode $t-1$. Model 
pengujian yang digunakan adalah dengan uji runs test. Hasil pengujian ditampilkan pada tabel berikut ini:

Tabel 4.7: Hasil Uji DW

\begin{tabular}{|c|c|c|c|c|c|}
\hline \multicolumn{6}{|c|}{ Model Summary ${ }^{b}$} \\
\hline Model & $\mathrm{R}$ & R Square & $\begin{array}{l}\text { Adjusted R } \\
\text { Square }\end{array}$ & $\begin{array}{l}\text { Std. Error of } \\
\text { the Estimate }\end{array}$ & $\begin{array}{l}\text { Durbin- } \\
\text { Watson }\end{array}$ \\
\hline 1 &, $392^{\mathrm{a}}$ &, 154 &, 114 & 33,01679 & 1,630 \\
\hline
\end{tabular}

Sumber: Data diolah 2021

Tabel diatas menunjukkan nilai durbin watson sebesar 1,630 dimana angka tersebut berada diantara -2 dan $+2(-2 \leq \mathrm{DW} \geq+2)$, maka dapat disimpulkan bahwa tidak terdapat masalah autokorelasi pada data yang diuji karena dapat cukup random untuk digunakan.

\section{Analisis Regresi Linier Berganda}

Tabel 4.8: Hasil Analisis Regresi Linier Berganda

\begin{tabular}{|c|c|c|c|c|c|c|}
\hline \multicolumn{7}{|c|}{ Coefficients $^{\mathrm{a}}$} \\
\hline & & \multicolumn{2}{|c|}{$\begin{array}{l}\text { Unstandardized } \\
\text { Coefficients }\end{array}$} & \multirow{2}{*}{$\begin{array}{c}\text { Standardized } \\
\text { Coefficients } \\
\text { Beta } \\
\end{array}$} & \multirow[b]{2}{*}{$t$} & \multirow[b]{2}{*}{ Sig. } \\
\hline \multicolumn{2}{|c|}{ Model } & $\mathrm{B}$ & Std. Error & & & \\
\hline \multirow[t]{3}{*}{1} & (Constant) & $-38,144$ & 30,706 & & $-1,242$ & ,221 \\
\hline & Perencanaan pajak & 291,324 & 110,969 &, 373 & 2,625 &, 012 \\
\hline & $\begin{array}{l}\text { Konservatisme } \\
\text { akuntansi }\end{array}$ & 26,670 & 35,684 &, 106 & ,747 &, 459 \\
\hline
\end{tabular}

a. Dependent Variable: Nilai perusahaan

Sumber: Data diolah 2021

Koefisien regresi dari hasil pengolahan data diatas dapat dibuatkan persamaan regresinya sebagai berikut:

\section{Uji Koefisien Determinasi}

$$
\begin{aligned}
& \mathrm{Y}=\alpha+\beta 1 \mathrm{X} 1+\beta 2 \mathrm{X} 2+\mathrm{e} \\
& \mathrm{Y}=-38,144+291,324 \mathrm{X} 1+26,670 \mathrm{X} 2+\mathrm{e}
\end{aligned}
$$

Koefisien determinasi (Adjusted $R$ Square) pada intinya mengukur seberapa jauh kemampuan model dalam menerangkan variasi variabel dependen. Dalam output SPSS, koefisien determinasi terletak pada tabel model dan tertulis Adjusted $R$ square" (Ghozali, 2011:97).

\begin{tabular}{|c|c|c|c|c|}
\hline \multicolumn{5}{|c|}{ Model Summary } \\
\hline Model & $\mathrm{R}$ & R Square & $\begin{array}{l}\text { Adjusted R } \\
\text { Square }\end{array}$ & $\begin{array}{l}\text { Std. Error of } \\
\text { the Estimate }\end{array}$ \\
\hline 1 &, $392^{\mathrm{a}}$ &, 154 &, 114 & 33,01679 \\
\hline
\end{tabular}

Tabel 4.9: Hasil Uji R Square

Sumber: Data diolah 2021

Tabel diatas memperlihatkan nilai Adjusted $R$ Square sebesar 0,114 atau 11,4\%. Hasil ini menunjukkan bahwa variabel perencanaan pajak dan konservatisme akuntansi dapat mempengaruhi variable nilai perusahaan sebesar $11,4 \%$. Sedangkan sisanya sebesar 0,886 atau $88,6 \%$ dipengaruhi oleh variabel lain yang tidak diuji dalam penelitian ini. 


\section{Uji Statistik t (parsial)}

Untuk melihat besarnya pengaruh perencanaan pajak dan konservatisme akuntansi terhadap nilai perusahaan secara parsial digunakan uji t. "Apabila nilai $t$ hitung $>t$ tabel maka dapat disimpulkan bahwa variabel independen berpengaruh secara parsial terhadap variabel dependen. Apabila nilai $\mathrm{t}$ hitung $<\mathrm{t}$ tabel maka dapat disimpulkan bahwa variabel independen tidak berpengaruh terhadap variabel dependen secara parsial. Kemudian apabila nilai probabilitas $t$ hitung lebih kecil dari tingkat kesalahan $\alpha=0,05$ maka dapat dikatakan bahwa variabel independen mempengaruhi secara signifikan terhadap variabel dependen. Sedangkan apabila nilai probabilitas thitung lebih besar dari tingkat kesalahan $\alpha=0,05$ maka dapat dikatakan bahwa variabel independen tidak berpengaruh signifikan terhadap variabel dependen" (Ghozali, 2011). Hasil perhitungan uji t dari penelitian ini sebagai berikut:

Tabel 4.10: Hasil Uji Parsial

\begin{tabular}{|c|c|c|c|c|c|c|}
\hline \multicolumn{7}{|c|}{ Coefficients $^{\mathrm{a}}$} \\
\hline & & \multicolumn{2}{|c|}{$\begin{array}{l}\text { Unstandardized } \\
\text { Coefficients }\end{array}$} & \multirow{2}{*}{$\begin{array}{c}\text { Standardized } \\
\text { Coefficients } \\
\text { Beta }\end{array}$} & \multirow[b]{2}{*}{$\mathrm{t}$} & \multirow[b]{2}{*}{ Sig. } \\
\hline \multicolumn{2}{|c|}{ Model } & B & Std. Error & & & \\
\hline \multirow[t]{3}{*}{1} & (Constant) & $-38,144$ & 30,706 & & $-1,242$ & ,221 \\
\hline & Perencanaan pajak & 291,324 & 110,969 & ,373 & 2,625 & 012 \\
\hline & $\begin{array}{l}\text { Konservatisme } \\
\text { akuntansi }\end{array}$ & 26,670 & 35,684 & , 106 &, 747 & ,459 \\
\hline
\end{tabular}

a. Dependent Variable: Nilai perusahaan

Sumber: Data diolah 2021

\section{1) Pengaruh Perencanaan Pajak terhadap Nilai Perusahaan}

Hasil pengujian secara parsial menunjukkan t-hitung variabel perencanaan pajak $\left(\mathrm{X}_{1}\right)$ adalah 2,625 sementara t-tabel dengan $\alpha=5 \%$ dan $\mathrm{df}=(\mathrm{n}-\mathrm{k})$ adalah $\mathrm{df}=(45-2)=43$, maka $\mathrm{t}-$ tabel $(0.05 ; 43)=1.68107$ sehingga t-hitung $>$ t-tabel $(2.625>1.6810)$ sehingga dapat ditarik kesimpulan bahwa variabel independen perencanaan pajak $\left(\mathrm{X}_{1}\right)$ berpengaruh terhadap variabel dependen nilai perusahaan (Y). Kemudian nilai probabilitas sig. perencanaan pajak $<0,05(0,01<0,05)$ maka dapat dikatakan terdapat pengaruh signifikan dari variabel perencanaan pajak $\left(\mathrm{X}_{1}\right)$ terhadap variabel nilai perusahaan $(\mathrm{Y})$.

Hasil penelitian ini mendukung penelitian terdahulu yang dilakukan oleh Muhammad Hidayat et al, (2016), Pandu Dewanata (2016) dan Herawati et al, (2016) yang mengatakan bahwa Perencaaan Pajak berpengaruh signifikan terhadap Nilai Perusahaan.

"Perusahaan yang melaksanakan perencanaan pajak bisa meningkatkan Nilai Perusahaan. Karena dengan melaksanakan perencanaan pajak, perusahaan bisa lebih efektif dalam membayarkan pajak terutangnya serta terlihat tertib dalam kewajiban perpajakannya".

\section{2) Pengaruh Konservatisme Akuntansi terhadap Nilai Perusahaan}

Hasil pengujian secara parsial untuk variable kedua ini menunjukkan t-hitung variabel konservatisme akuntansi $\left(\mathrm{X}_{2}\right)$ adalah 0,747 sementara t-tabel dengan $\alpha=5 \%$ dan $\mathrm{df}=(\mathrm{n}-\mathrm{k})$ adalah $\mathrm{df}=(45-2)=43$, maka $\mathrm{t}$-tabel $(0.05 ; 43)=1.68107$ sehingga $\mathrm{t}$-hitung $<\mathrm{t}$-tabel $(0,747$ $<$ 1.68107) maka dapat disimpulkan bahwa variabel independen konservatisme akuntansi $\left(\mathrm{X}_{2}\right)$ tidak berpengaruh terhadap variabel dependen nilai perusahaan $(\mathrm{Y})$. Kemudian nilai probabilitas sig. konservatisme akuntansi > 0,05 $(0,459>0,05)$ maka dapat dikatakan tidak terdapat pengaruh signifikan dari variabel konservatisme akuntansi $\left(\mathrm{X}_{2}\right)$ terhadap variabel nilai perusahaan $(\mathrm{Y})$.

Hasil penelitian ini tidak sejalan dengan penelitian yang dilakukan oleh umpal Manik (2018) yang mengatakan bahwa Konservatisme Akuntansi berpengaruh signifikan terhadap Nilai Perusahaan serta penelitian Shelly Elgy Augustine (2016) yang mengatakan bahwa Konservatisme Akuntansi berpengaruh negatif terhadap Nilai Perusahaan.

Tetapi hasil penelitian ini mendukung penelitian Ulfa Rafida Isnaningrum (2016) mengatakan bahwa Konservatisme Akuntansi tidak berpengaruh secara signifikan 
terhadap Nilai Perusahaan. "Hal ini disebabkan oleh adanya kecenderungan investor tidak lagi melihat Konservatisme Akuntansi dalam menilai saham perusahaan sehingga tidak menaikkan harga pasar saham yang mengakibatkan tidak meningkat pula penilaian ekuitas para investor" (Yenti \& Syofyan, 2013). Tidak menaiknya harga saham tersebut membuat Nilai Perusahaan juga tidak menaik karena Nilai Perusahaan tercermin dalam nilai pasar dari suatu ekuitas perusahaan dan nilai pasar utang.

\section{Uji Statistik F (simultan)}

"Uji F digunakan untuk mengetahui apakah variabel independen secara bersama-sama berpengaruh terhadap variabel dependen atau untuk mengetahui apakah model regresi dapat digunakan untuk memprediksi variabel dependen atau tidak. Jika nilai probabilitas $>0,05$ maka Ho diterima atau Ha ditolak yang berarti bahwa semua variabel independen tidak mempunyai pengaruh secara bersama-sama (simultan) terhadap variabel dependen. Jika nilai probabilitas < 0,05, maka Ho ditolak atau Ha diterima yang berarti bahwa semua variabel independen mempunyai pengaruh secara bersama-sama (simultan) terhadap variabel dependen".

Tabel 4.11: Hasil Uji F Simultan

\begin{tabular}{|c|c|c|c|c|c|c|}
\hline \multicolumn{7}{|c|}{ ANOVA $^{\mathrm{a}}$} \\
\hline \multicolumn{2}{|c|}{ Model } & $\begin{array}{l}\text { Sum of } \\
\text { Squares }\end{array}$ & df & Mean Square & $\mathrm{F}$ & Sig. \\
\hline \multirow[t]{3}{*}{1} & Regression & 8336,588 & 2 & 4168,294 & 4,824 &, $030^{b}$ \\
\hline & Residual & 45784,556 & 42 & 1090,108 & & \\
\hline & Total & 54121,145 & 44 & & & \\
\hline
\end{tabular}

a. Dependent Variable: Nilai perusahaan

b. Predictors: (Constant), Konservatisme akuntansi, Perencanaan pajak

Sumber: Data diolah 2021

Berdasarkan pengujian diatas diketahui bahwa nilai $\mathrm{F}$ hitung diperoleh sebesar 3,824 sedangkan nilai $\mathrm{F}$ tabel sementara $\mathrm{F}$ tabel dengan $\alpha=5 \%$ dan $\mathrm{df}=(\mathrm{k}-1)=(2-1)=1$ dan $\mathrm{df} 2=(\mathrm{n}-$ $\mathrm{k})=(45-2)=43$, didapat $\mathrm{F}$ tabel sebesar 4,07. Dengan demikian $\mathrm{F}$ hitung $>\mathrm{F}$ tabel $(4,824>$ 4,07) maka dapat disimpulkan bahwa secara bersama-sama, variabel independen memiliki pengaruh signifikan terhadap variabel dependen. Kemudian terlihat dari nilai probabilitas dari tabel yaitu sebesar $0.03<0.05$ menjelaskan bahwa variabel perencanaan pajak dan konservatisme akuntansi secara bersama-sama (simultan) mempunyai pengaruh yang signifikan terhadap nilai perusahaan.

\section{KESIMPULAN}

Kesimpulan yang dapat diambil dari hasil pengujian yang sudah dilakukan yaitu perencanaan pajak berpengaruh secara signifikan terhadap nilai perusahaan sub sektor food and beverage yang terdaftar di Bursa Efek Indonesia (BEI) dari tahun 2014 sampai tahun 2018. Konservatisme akuntansi tidak berpengaruh secara signifikan terhadap nilai perusahaan sub sektor food and beverage yang terdaftar di Bursa Efek Indonesia (BEI) dari tahun 2014 sampai tahun 2018. Serta perencanaan pajak dan konservatisme akuntansi secara simultan berpengaruh signifikan terhadap nilai perusahaan sub sektor food and beverage yang terdaftar di Bursa Efek Indonesia (BEI) dari tahun 2014 sampai tahun 2018.

\section{DAFTAR PUSTAKA}

Afriyadi, A. D. (2017, Juli 21). Retrieved Februari 28, 2020, from Liputan6.com: https://m.liputan6.com/bisnis/read/3030569/tersandung-kasus-saham-tiga-pilarsejahtera-food-terjun-bebas

Dewanata, P. (2016). Pengaruh Perencanaan pajak terhadap Nilai Perusahaan dengan Kualitas Corporate Governance sebagai Variabel Moderasi 
Fajaria, A. Z. (2015). Pengaruh Keputusan Investasi, Keputusan Pendanaan dan Kebijakan dividen terhadap Nilai Perusahaan.

Ghozali, I. (2018). Aplikasi Analisis Multivariate dengan Program IBM SPSS 25. Semarang: Badan Penerbit Universitas Diponegoro.

Lestari, N., \& Ningrum, S. A. (2018). Pengaruh Manajemen Laba dan Tax Avoidance terhadap Nilai Perusahaan dengan Kualitas Audit sebagai Variabel Moderasi.

Manik, T. (2018). Pengaruh Manajemen Laba dan Konservatisme Akuntansi terhadap Nilai Perusahaan dengan Kinerja Perusahaan sebagai Variabel Pemoderasi.

Pradnyana, I. B., \& Noviari, N. (2017). Pengaruh Perencanaan Pajak Terhadap Nilai Perusahaan Dengan Transparansi Moderasi sebagai Variabel Moderasi.

Saraswati, T. (2018). Pengaruh Manajemen Laba dan Perencanaan Pajak terhadap Nilai Perusahaan dengan Corporate Governance sebagai variabel moderasi.

Savitri, E. (2016). Konservatisme Akuntansi. Yogyakarta: Pustaka Sahila Yogyakarta.

www. kemenperin.go.id/artikel/17503/Industry-4.0-TingkatkanProduktivitas,-Tenaga-Kerja,dan-Pasar

Kemenperin. 2018. Brief Making Indonesia 4.0.

Kemenperin. 2018. Kebijakan Sektor Industri Makanan dan Minuman dalam Rangka

Implementasi Roadmap Industri 4.0 